\title{
Why Africa Needs The COP Project Badly
}

\author{
Jan-Erik Lane \\ Fellow at the Public Policy Institute, Belgrade
}

\begin{abstract}
To meet the demands for rising living standards in this century, Afican countries need to upgrade its energy supply. They can only do it with massive support from the COP project, which would reduce the global warming risk, globally. Solar power parks like Quarzazate is the future for the African continent.
\end{abstract}

Keywords: African energy and $\mathrm{CO} 2$ emissions, fresh and clean water, lakes and rivers, new and old renewables, coal or oil and gas dependency, Super Fund.

\section{INTRODUCTION}

In the climate change process, the African countries suffer badly from the biggest externality in human history (Stern, 2007, 2015). They are not among the big emitters of greenhouse gases or CO2: s. But they have to adapt their societies and economies to temperature rise that will most probably go over +2 degrees, and maybe even +3 degrees. How to cope? If temperature raises goes even further towards $+4-6$ degrees, life will be threatened. How can people work under too hot circumstances? Water? The wildlife?

Yet, African governments have promised to contribute towards the COP21 objectives of decarbonisation by transforming their energy systems. How to pay? Even if African nations carry out their responsibilities under the UN Treaty, there is no guarantee that the big emitters of C02:s will not renege. And then we have the danger of the new methane emissions.

There is a basic catch-22: The African continent uses less energy per capita than the other global continents, which entails that total emissions of CO2s are lower than in Asia, America and Europe. Yet, Africa badly needs more energy, as it is the capacity to do work that result in income and wealth (Sachs, 2015). If Africa could increase its energy share globally, it could reduce poverty and first and foremost secure its water supplies.

\section{ENERGY ON THE CONTINENT}

The countries on the African continent do not belong to the great polluters of CO2s in the world. Only a few of them have large C02s like Egypt, Algeria, South Africa and Nigeria, but they do not rank among the really large 29 polluters in the world. This basic fact reflects their level of affluence, as energy and GDP are closely related. Consider Figure 1 with the global energy scene. 


\section{FIGURE 1. Global energy}
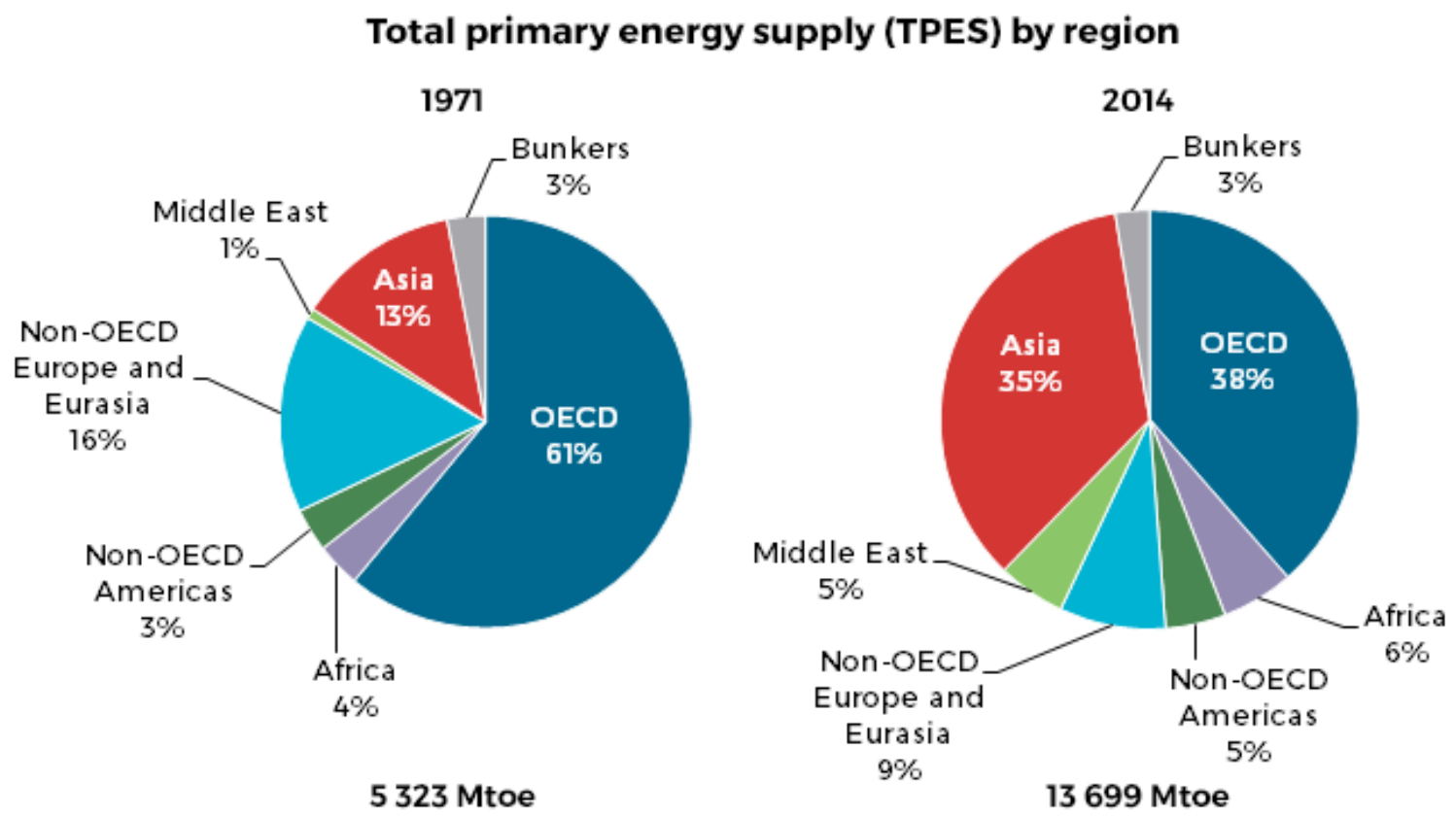

Source: https://www.iea.org/newsroom/news/2016/august/iea-data-shows-global-energyproduction-and-consumption-continue-to-rismle.ht

It is small wonder that the African continent is the poorest, given its low share of global energy consumption. The population of Africa is increasing fast, meaning that much more energy is needed for economic and social development, but the COP2 1 decarbonisation project must be respected!

African countries are unique in the sense that they do not contribute much to climate change, but they could stand to suffer enormously from global warming - the external effects of climate change. They range from excessive heat, constant need of air-conditioning (also augmenting emissions), droughts, ocean acidification, food shortages, and insupportable working conditions for peasants, etc. Yet, African governments can argue that they need much support for energy transformation, given the low share of global emissions for the continent - see Figure 2 . 
FIGURE 2. Global emissions of $\mathrm{CO} 2$

\section{Not all regions are major contributors to $\mathrm{CO}_{2}$ emissions

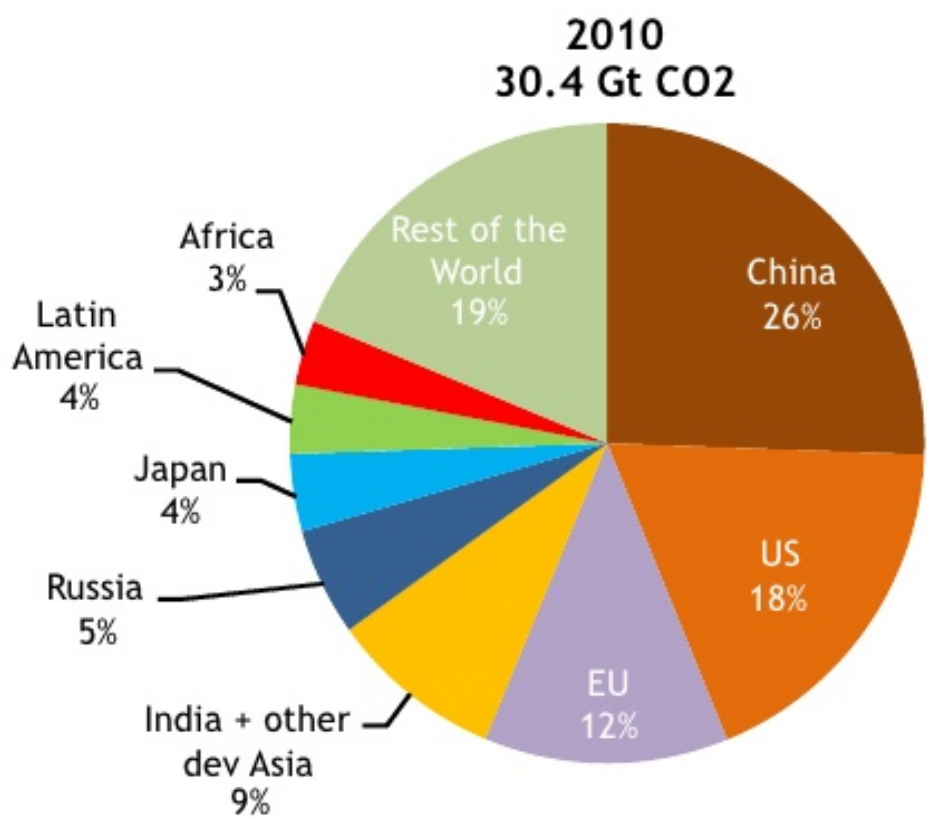

Africa constitutes $15 \%$ of the global population, but just $3 \%$ of global $\mathrm{CO}_{2}$-emissions

\section{Source: http://www.slideshare.net/internationalenergyagency/birol-18th-meeting-of-the- africa-partnership-forum}

Economic development in poor countries as well as economic growth in advanced countries tends to trump environmentalism. This sets up the energy-emissions conundrum for mankind in this century: Affluence requires energy, as energy is the capacity to do work that renders income - see global Figure 3; but as energy consumption augments, so do emissions of GHG:s or CO2:s (Appendix 1). How to fundamentally transform global energy consumption?

FIGURE 3. GDP against energy per person (all countries)

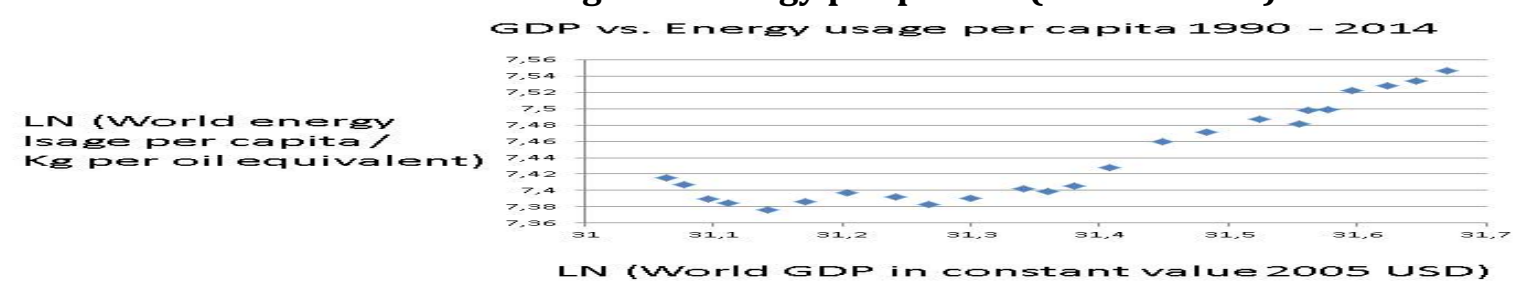

What is at stake for most people who understand the risks with climate change is not the desirability of decarbonisation in some form or another. They crux of the matter is feasibility: How to promote decarbonisation so that real life outcomes come about? The COP21 framework, and its three objectives, namely:

* Halting the increase in carbon emission up to 2020 (Goal I),

* Reducing CO2:s up until 2030 with 40 per cent (Goal II),

* Achieve more or less total decarbonisation until 2075 (Goal III), 
will prove too demanding for most countries, I dare suggest - also for African nations in dire need of the promised Super Fund.

African governments must now start energy-emissions policy-making within the framework of the UN Convention on Climate Change. Positively, they can argue that energy consumption is far too low on the African continent. The population is rapidly growing and needs massive electricity supply. Simple global energy-emissions fairness requires this.

Negatively, African nations are much dependent upon coal - wood coal except South Africa that uses stone coal - and oil and gas in the oil producing countries and Egypt. Most African countries employ wood coal and its derivatives, which maintain the continent in poverty. The COP21 project should be used by African governments for rapid electrification by means of NEW renewables, like e.g solar power.

The energy-emissions conundrum applies also to the African continent, as C02:s is rising, driven by economic development. The situation in 1990 for 13 major African countries was as depicted in Figure 4.

FIGURE 4. GDP-CO2 link in 1990: $y=1,34 x ; R^{2}=0,87$

LN (CO2

Emissions / kg)

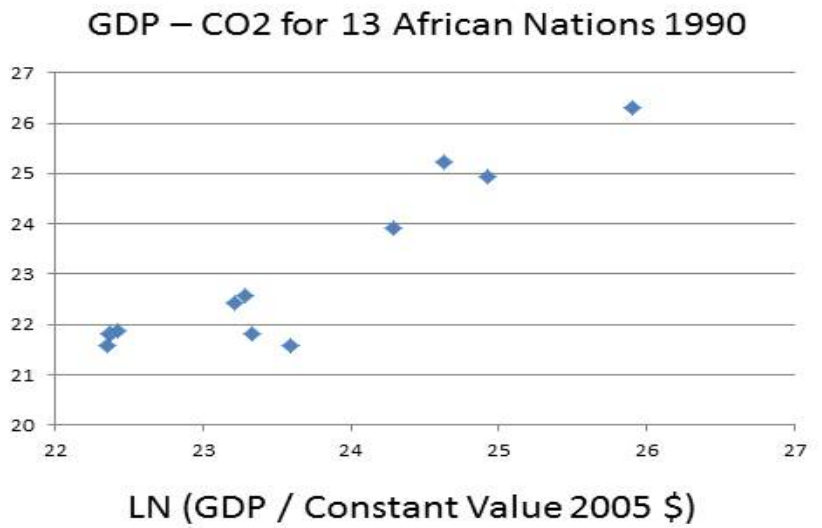

20 years later, emissions have increased following economic development. Surely, the UN would be interested in seeing C02:s low in Africa, but then it must help with a fundamental energy transition from solids and fossil fuels to NEW renewables. (Figure 5). 
FIGURE 5. GDP-CO2 link 2014: $y=1,47 x ; R^{2}=0,93$

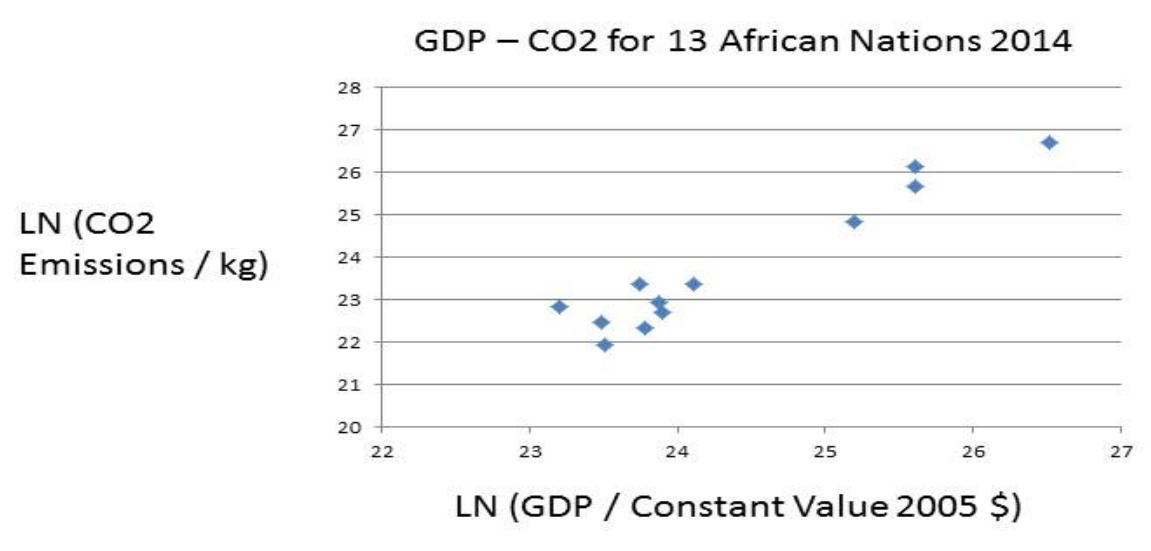

\section{ENERGY DEFICIT CONSEQUENCES}

African countries are poor because they have too little energy. Thus, they have much less GHGs than Asia. Yet, they need the COP project of the UNFCCC to renew their energy sources and move from fossil fuels and traditional renewables to solar power. Hydro power depends upon water availability that shrinks with global warming.

African energy deficit is conducive to a dire environment with enormous damages and risks. Consider the following global Figures. Figure 6 shows how low energy leads to unsafe environmental.

FIGURE 6: Energy and environmental risk exposure

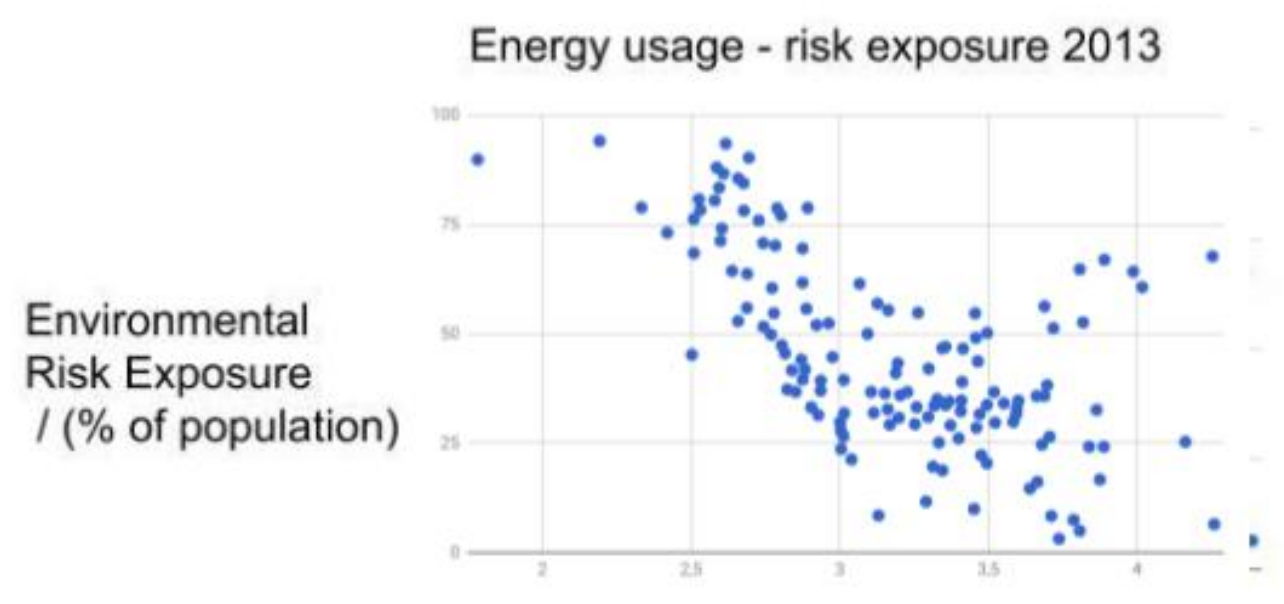

Log(Energy usage / capita (kg oil equivalent))

Source: Environmental Performance Index, Yale University, https://epi.envirocenter.yale. IEA Statistics (C) OECD/IEA 2014 (http://www.iea.org/stats/inde 
Low energy use leads to poverty, malnutrition, deceases, lack of potable water, insufficient sanitation, etc.

Typical of many African nations is the lack of stable electricity, which hampers everything and reduces environmental viability. Figure 7 has the global picture.

FIGURE 7. Energy and electricity access

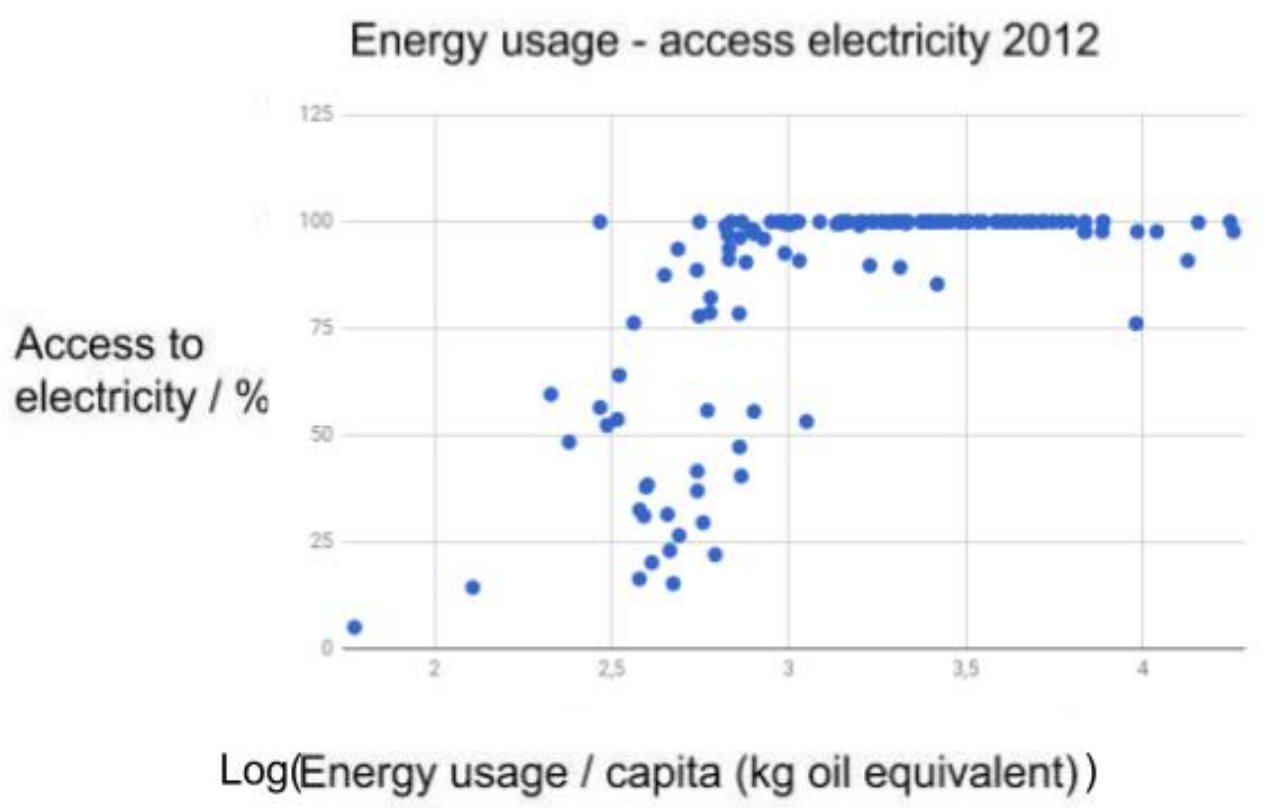

Source: Environmental Performance Index, Yale University, https://epi.envirocenter.yale. IEA Statistics (C) OECD/IEA 2014 (http://www.iea.org/stats/inde

The access to safe and stable electricity is crucial for health, schools, food, water, etc.

FIGURE 8. Links of energy with proper sanitation.

Energy usage - access sanitation 2014

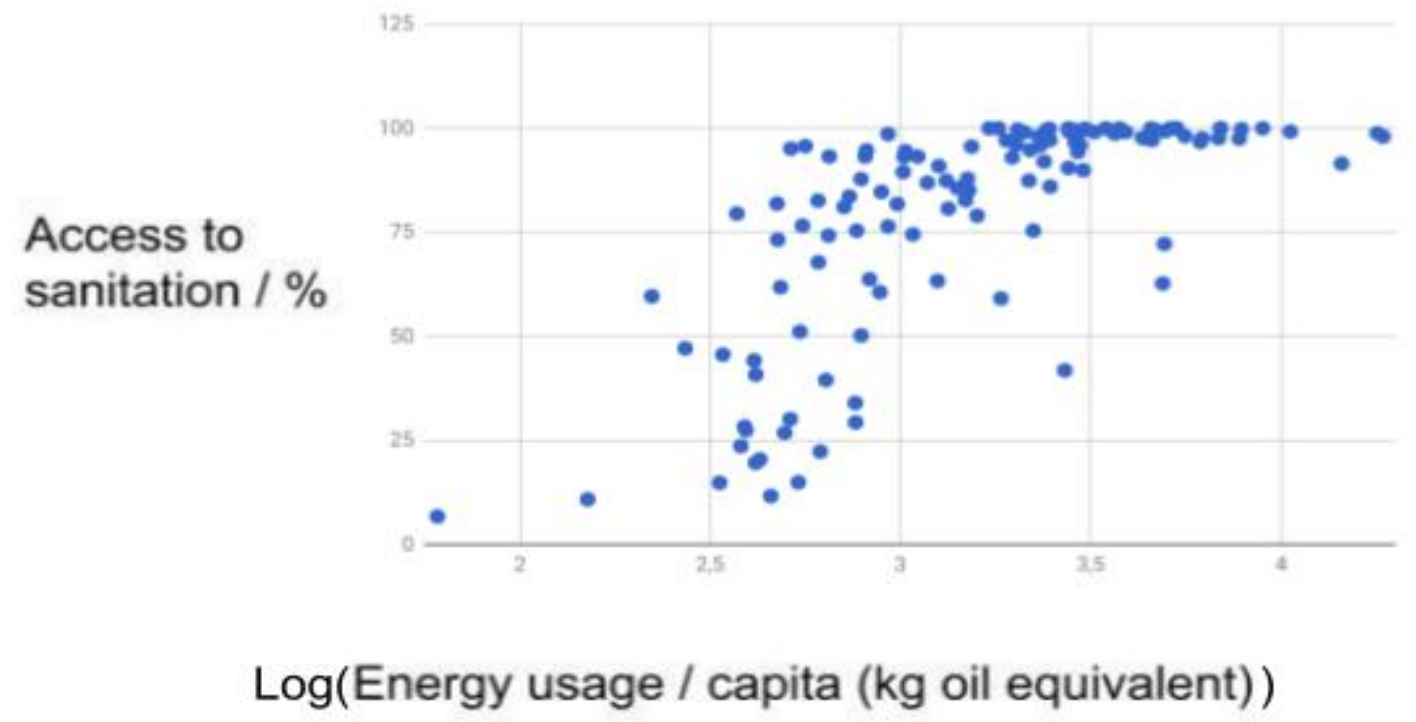

Source: Environmental Performance Index, Yale University, https://epi.envirocenter.yale. IEA Statistics (C) OECD/IEA 2014 (http://www.iea.org/stats/inde 
Especially, the rapidly growing African mega-cities lack entirely sewage plants. Thus, dirty water is put into the big rivers or lakes where other cities downstream or close by take their potable water.

Africa needs much more energy of a new kind.

\section{WATER PROBLEM IN AFRICA}

Environmental policy-making and implementation is inherently about politics, from its start to the finish, if it exists. Governments, national, regional and local have the responsibility for the environments and it may find partners - communities, civil society and business - in the policy cycle relating to ecology issues. Coordination failure is often occurring due to myopia, opportunism and conflicts between states or governments in a country.

Environmental degradation is to be found for most lakes and rivers around the globe. But the extent of damage varies tremendously. What are often harmful for lakes and rivers are the construction dams for electricity generation.

The key question in relation to the degradation of lakes and rivers is: Will they shrink dramatically? Global warming and human exploitation work together to diminish lakes and rivers around the world, in several spectacular cases also on the African continent..

The most spectacular case of lake shrinking or disappearing today is Lake Chad in the centre of Sahara. It is now 1/5th of its size in 1970, when a public investigation and control mechanism was launched by the five neighbouring countries, to no avail. The lake is now only 7 meters deep and will disappear soon. The reason: human overuse for drinkable water and irrigation. Outcome: Population movements, or environmental refugees in politically instable countries.

The River Nile is loosening water due to the construction of several dams in Ethiopia and Sudan. Egypt has expressed concern for its water supply in the near future, but there is no formal intergovernmental regulation of this water conflict. The mighty Nile will soon no longer be so powerful, as the water flow from both the White and Blue Nile diminishes due to dams as well as the Mediterranean Sea eats into its delta with inflowing salt water. Outcome: increased water scarcity in Egypt with food shortages; severe political conflict between Egypt, Ethiopia and Sudan; more electricity for Ethiopia and Sudan.

In Africa, one may also wish to mention the river Niger and the Lake Victoria, when speaking of ecological disasters in the future. Both are deteriorating, Niger River due to dams and Lake Victoria due to human exploitation and global warming.

The situation is hardly much better in other parts of Africa: lakes are under deterioration because of human activities on the one hand - overfishing, waste and sewage disposal, and take out of water for various purposes - as well as global warming on the other hand; rivers increasingly come under pressure from dam construction, sewage and waste, as well as water take outs. This negative evaluation holds for among others the large lakes of Lake Malawi and Lake Tanganyika as well as for great rivers like The Congo, The Chobe, the Zambezi, etc. The River Congo has to cope with logging in addition to human pollution. Thus, legal or illegal harvest of the rain forest in the huge Congo Basin opens up roads that may be used for further exploitation.

Given the predicament of rivers and lakes in Africa, one may predict a shortage of fresh, clean, drinkable water soon with negative repercussions for food. 


\section{ABSENCE OF MODERN ENERGY SOURCES}

With the possible exception of the Quarzazate solar plant in Morocco, African countries relies mostly upon fossil fuels and traditional renewables like wood coal. Hydro power has become more important, but its sustainability may be doubted. Water resources are often shared between nations, causing tensions between states. Let us look at a few examples.

\section{Coal}

The RSA has a modern economy running on mainly coal (Figure 9). In transportation, it uses petroleum. This makes the RSA a major $\mathrm{CO} 2$ polluting nation. It wants to spread electricity to all shanti-towns, but with what energy source?

FIGURE 9- Energy consumption in RSA

Figure 1. Total primary energy consumption in South Africa, 2013

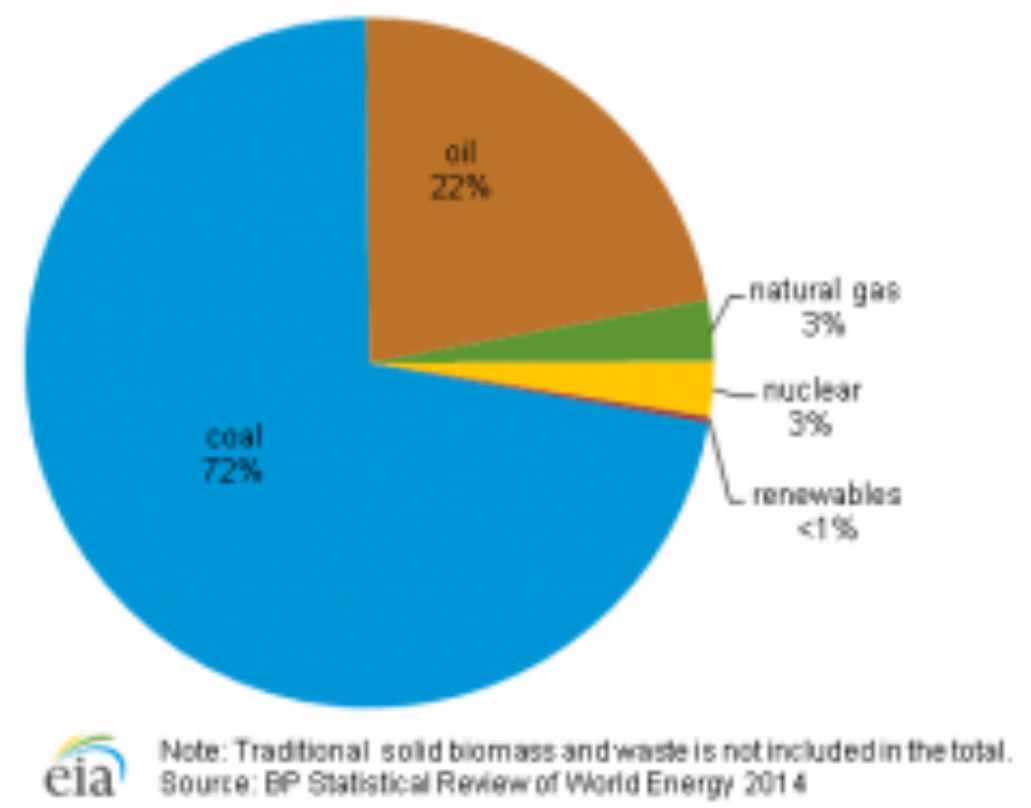

Does the RSA have the resources and motivation to cut the coal consumption radically and move to solar energy for instance? Or could the RSA renege on COP21 - the always available option in collective action endeavours?! 
Figure 10 shows the necessity of more energy for raising livings standards.

\section{GDP - Energy for South Africa $1990-2015$}

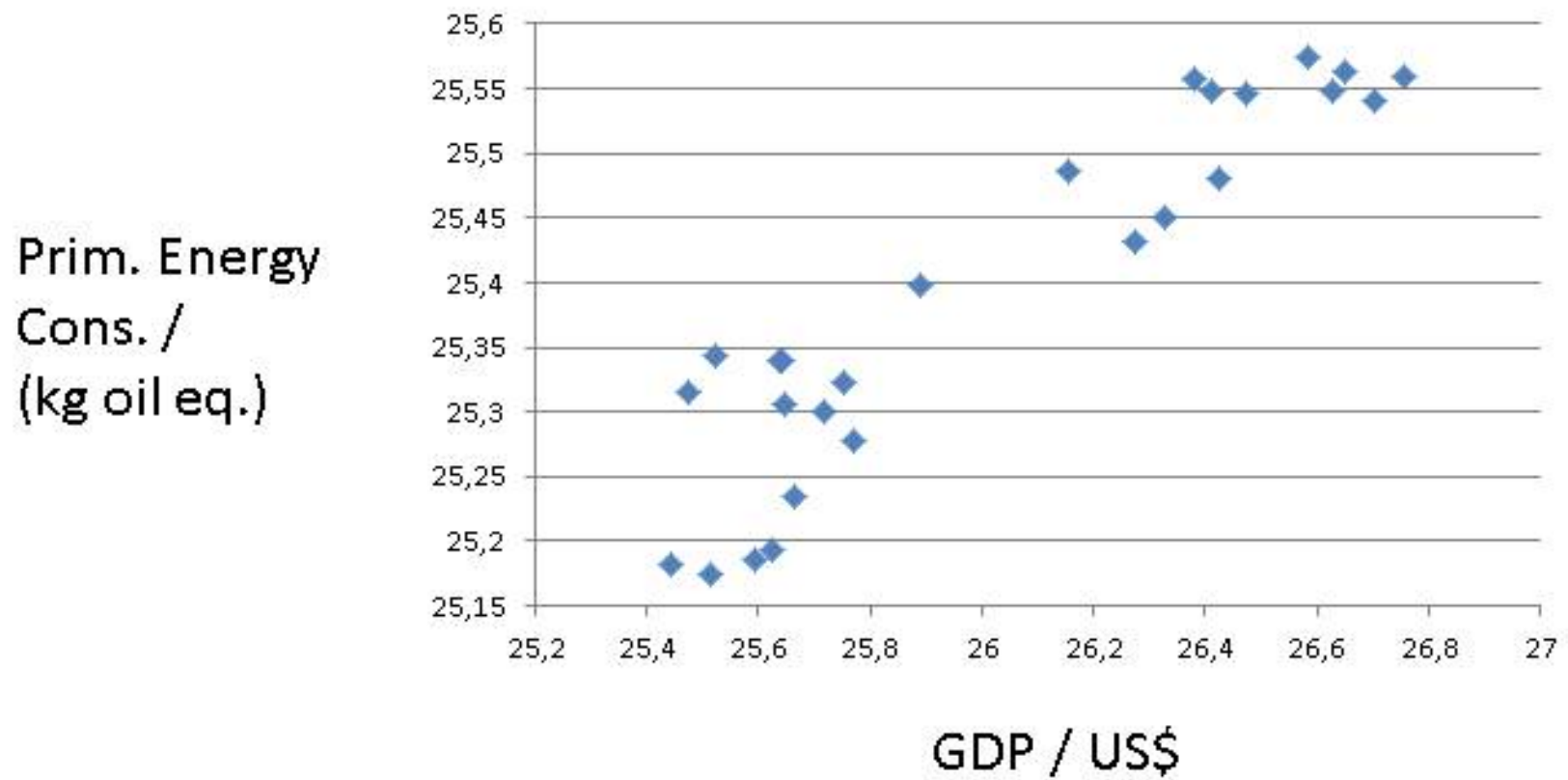

The promises made to the deprived population includes lots of energy demanding projects in health, housing, schooling, etc. Only a massive investment in solar power parks can deliver this, requiring support from the Super Fund in the COP effots.

\section{Oil}

Some African countries produce lots of oil and consume some of it themselves. One country almost only relies upon oil and gas.

\section{Algeria}

Algeria is a major exporter of natural gas and oil, Thus, we expect that it relies exclusively on fossil fuels, like Mexico, Iran and the Gulf States. Figure 11 verifies this expectation. 
FIGURE 11. Energy mix in Algeria

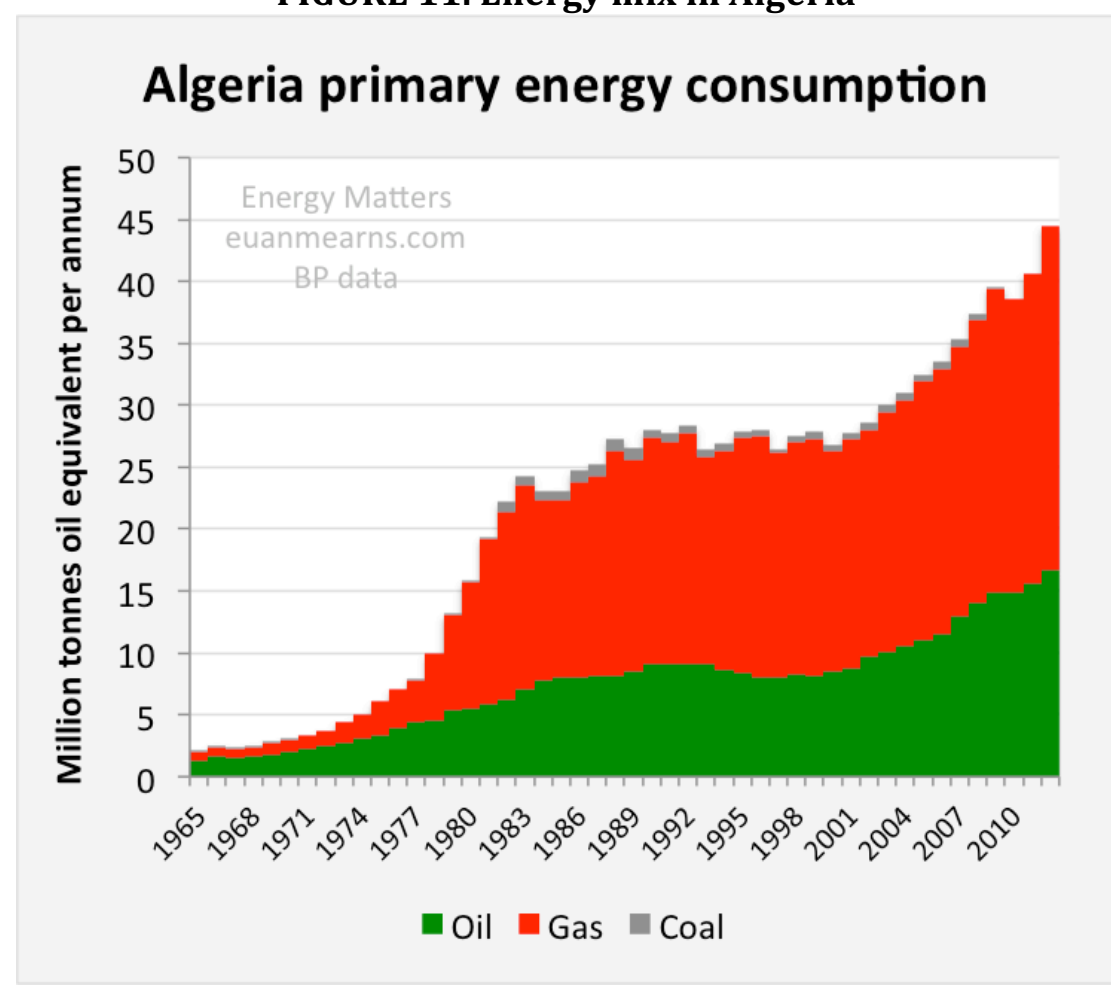

Source: http://euanmearns.com/post-peak-algeria/

Although Algeria may have great trust in the availability of future fossil fuels resources in the country, it still faces the demand for a 40\% reduction of its CO2 emissions from the COP21. Emissions have thus far followed the economic progress very closely- see Figure 12.

FIGURE 12. Link GDP-CO2 in Algeria

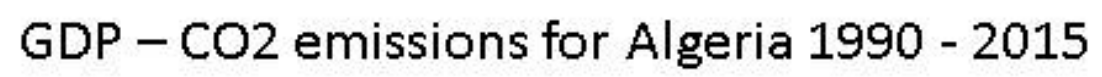

$\operatorname{LN}(\mathrm{CO} 2 / \mathrm{kg})$

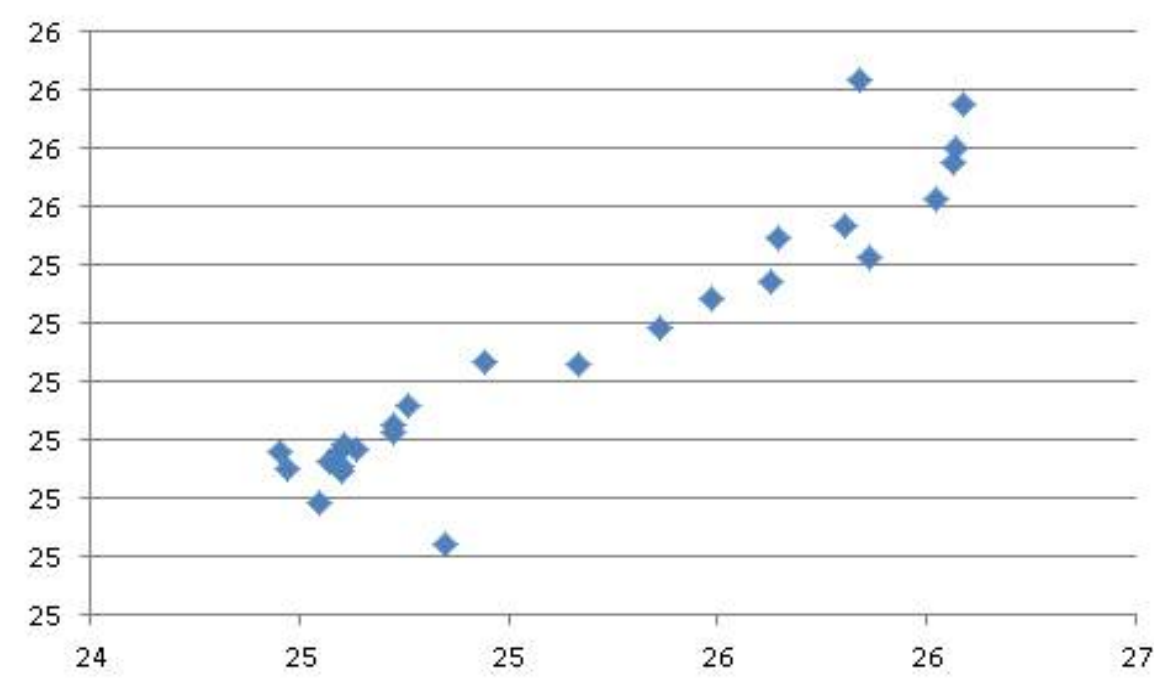

\section{LN (GDP/US\$)}

Algeria has much youth unemploymens an must care for its growing population. It needs a new energz source, namely solar power parks in Sahara. 


\section{Gas}

Egypt has a huge population with high unemployment and mass poverty besides a high level of political instability, resulting from religious conflicts. But surely it has electricity from ins giant Assuam dam and the Nile? No, it does not count for much for Egypt, where most people live in the Nile delta. CO2:s are on a sharp upward trend for Egypt dur to energy demand rising quickly (Figure 13).

FIGURE 13. Energy-GDP link for Egypt

$$
\text { GDP - Energy for Egypt } 1990-2015
$$

Prim. Energy

Cons. /

(kg oil eq.)

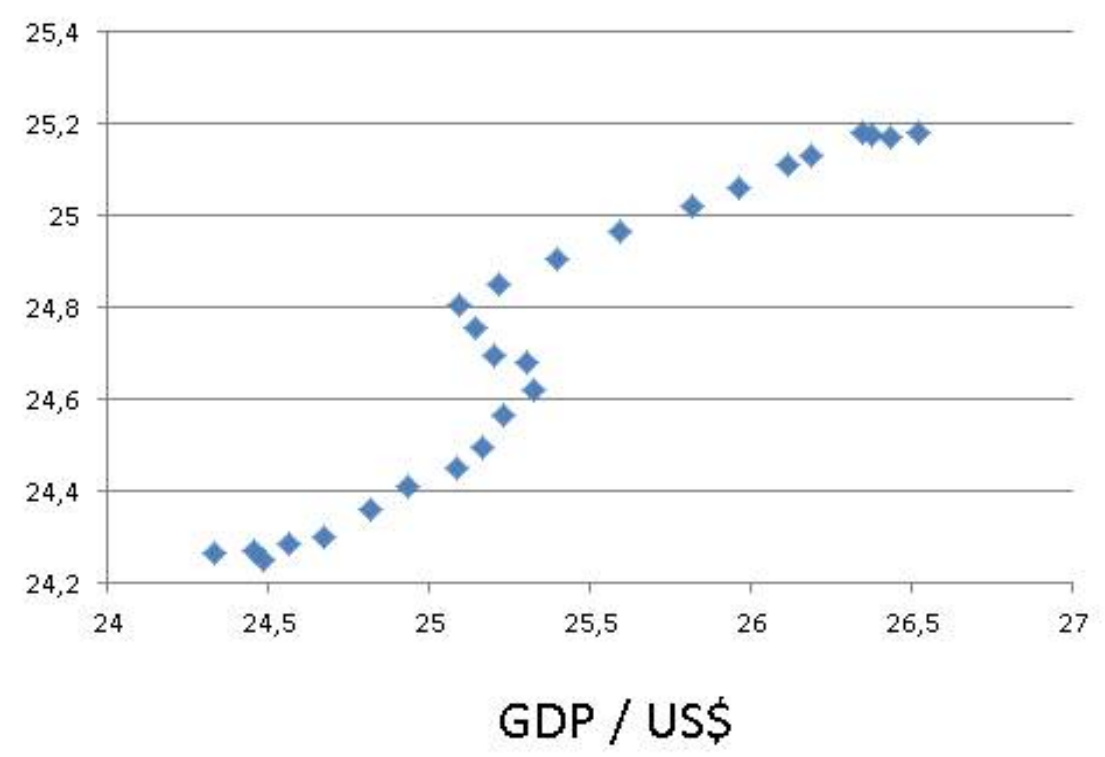

Egypt has an enormous growth in population. Its water resources are challenged by upstream countries. It builds a new capital, but CO2:s are rising sharply (Figure 14).

FIGURE 14. GDP-CO2 for Egypt: $y=1,02 x ; R^{2}=0,99$

GDP - CO2 emissions for Egypt 1990 - 2015

\section{$\mathrm{LN}(\mathrm{CO} 2 / \mathrm{kg})$}

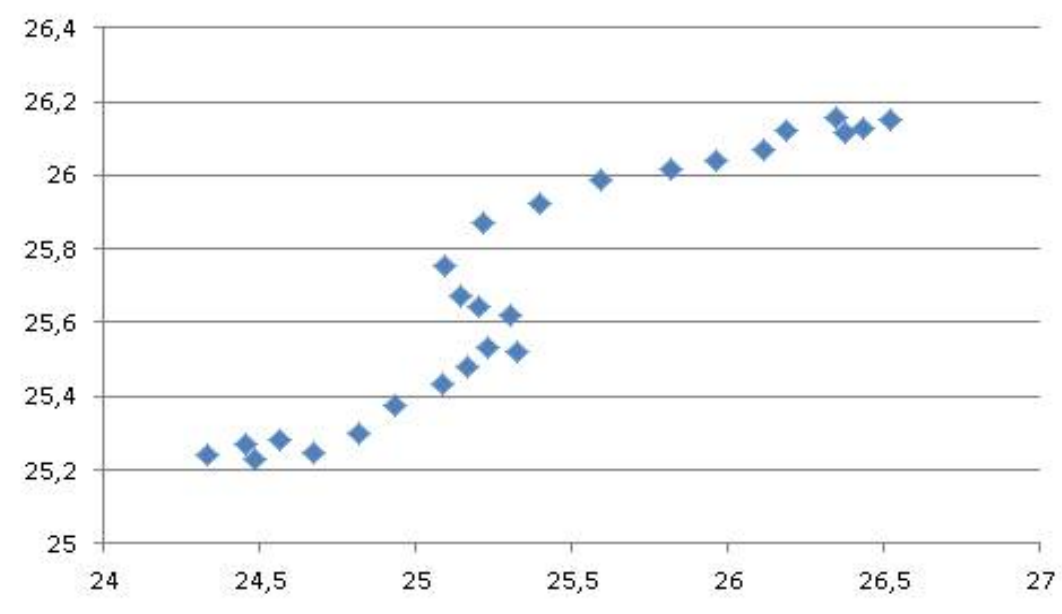

LN (GDP/US\$) 
It will be very difficult for Egypt to make the COP21 transformation, at least without massive external support. But where to build huge solar power plants in a country with terrorism, threat or actual? The share of hydro power is stunning low for a country with one of largest rivers in the world. Actually, the water of the Nile is the source of interstate confrontation between Egypt, Sudan and Ethiopia, because the latter two have started to exploit it recently.

\section{Wood Coal and Hydro Power}

In the climate change discussions and policy-making, it is often stated that renewables should be preferred over non-renewables. Yet, this statement must be strictly modified, as there are two fundamentally different renewables:

* Traditional renewables: wood, charcoal and dung. They are not carbon neutral. On the contrary, employing these renewables results in severe pollution, not only outside but also inside household;

* New renewables: solar, wind, geo-thermal and wave energy that are indeed carbon neutral, at least at the stage of functioning.

In the poor African countries with about half the population in agriculture and small villages, traditional renewables constitute the major source of energy.

\section{Kongo Kinshasa}

One understands the hefty use of wood coal in this giant country, so plagued by political instability, anarchy, anomie and civil wars with foreign involvement (Figure 15).

\section{FIGURE 15. DR KONGO}

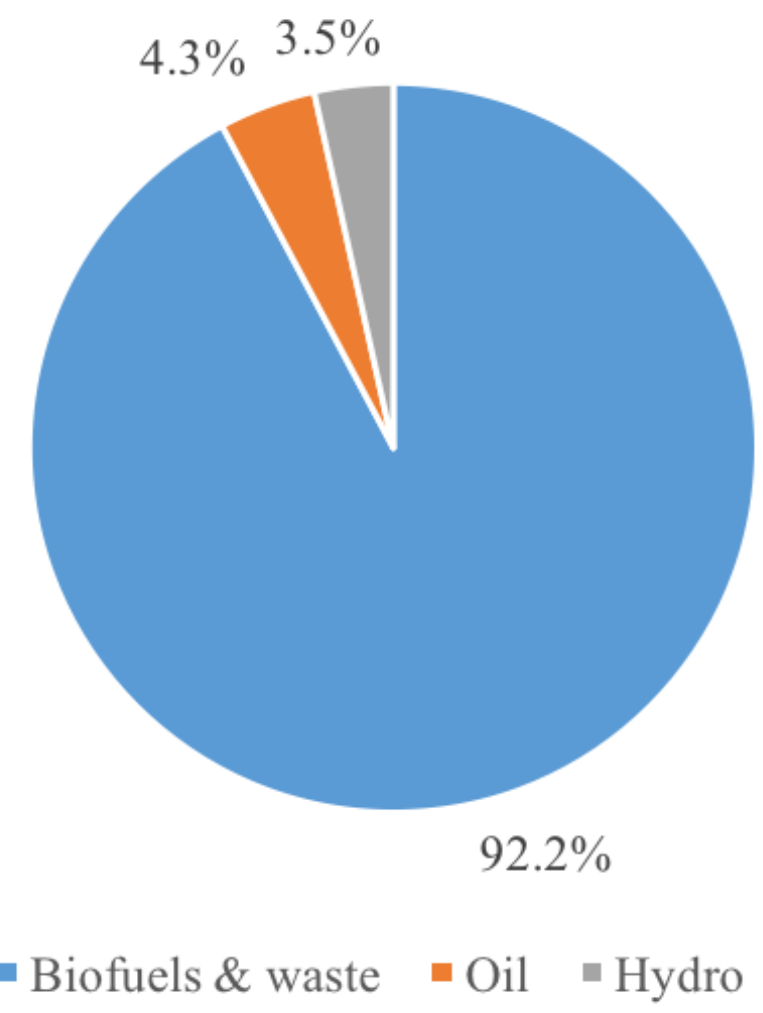

Source: Democratic Republic of Congo - Energy Outlook, Kungliga Tekniska Hoegskolan

One notes how little of hydro power has been turned into electricity in Kongo, but economic development and political instability, civil war and anarchy do not go together normally. At the same, one may argue that an extensive build-up of hydro power stations would pose a severe 
challenge to the fragile environment in the centre of Africa. Kongo can now move directly to modern renewables like solar power.

\section{Sudan}

The energy consumption of Sudan reflects this situation - Figure 16. The countries relying upon traditional renewables to an extent up to 50 per cent or higher will have to reflect upon how to bring these figures down sharply with modern renewables. It is an entirely different task than that of countries with too much fossil fuel dependency. Hydro power has increased in Sudan, which is a positive. But the water of the Nile can last only so long for three large energy power hungry nations, with Egypt fearing for water shortages in agriculture and potable water.

Sudan is dismally poor with deep-seated internal conflicts ethnically. How to move to large solar panel plats in a country with so much political instability resulting huge numbers of death from domestic violence?

FIGURE 15. Sudan's energy mix

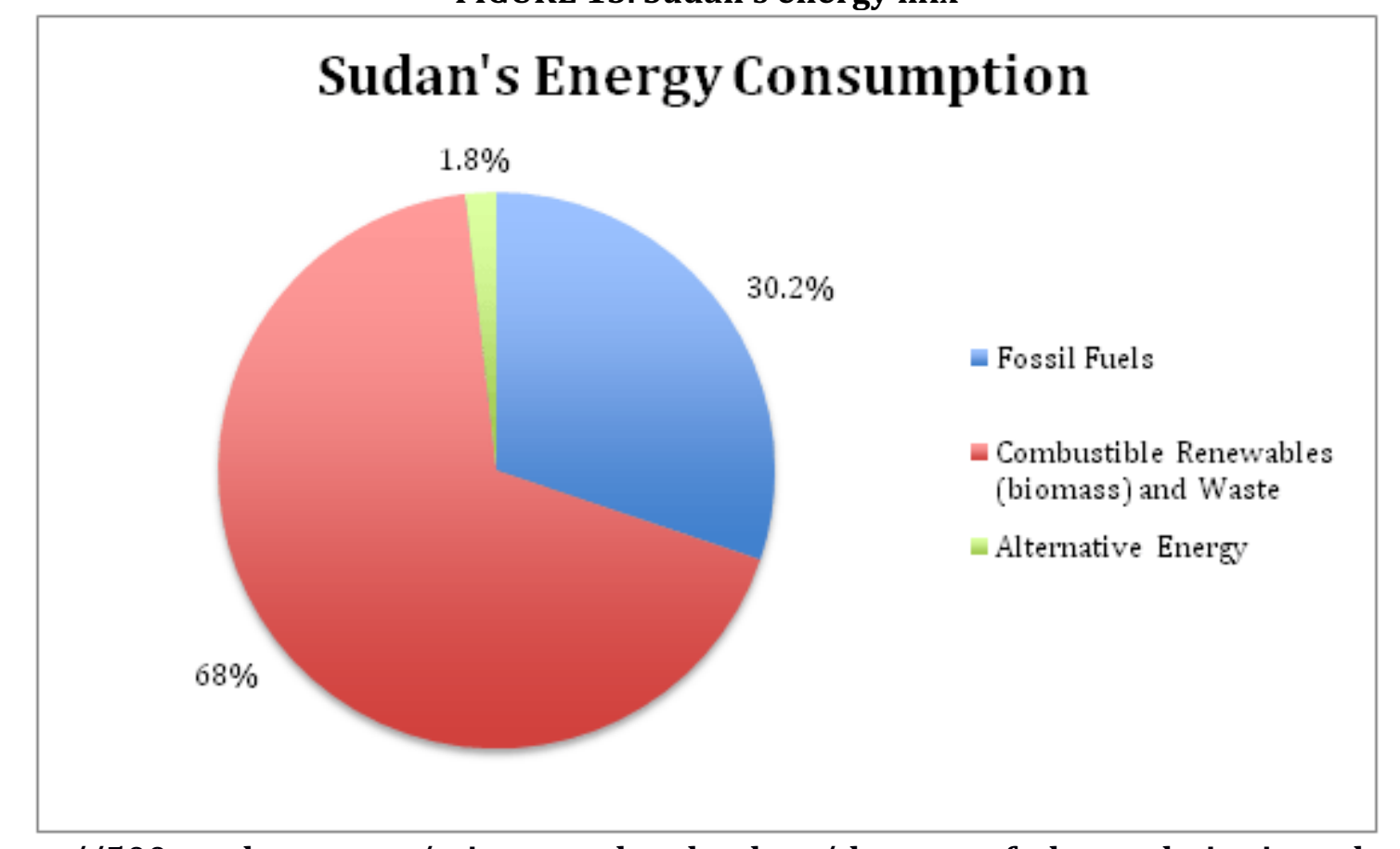

http://500wordsmag.com/science-and-technology/the-case-of-photovoltaics-in-sudan/

\section{Ethiopia}

The reliance upon traditional renewables is so high in neighbouring Ethiopia that electrification must be very difficult to accomplish over the large land area. Figure 17 displays a unique predicament, although a few hydro power stations have increased hydro power substantially since 2008. 
FIGURE 17. Ethiopia: Energy mix

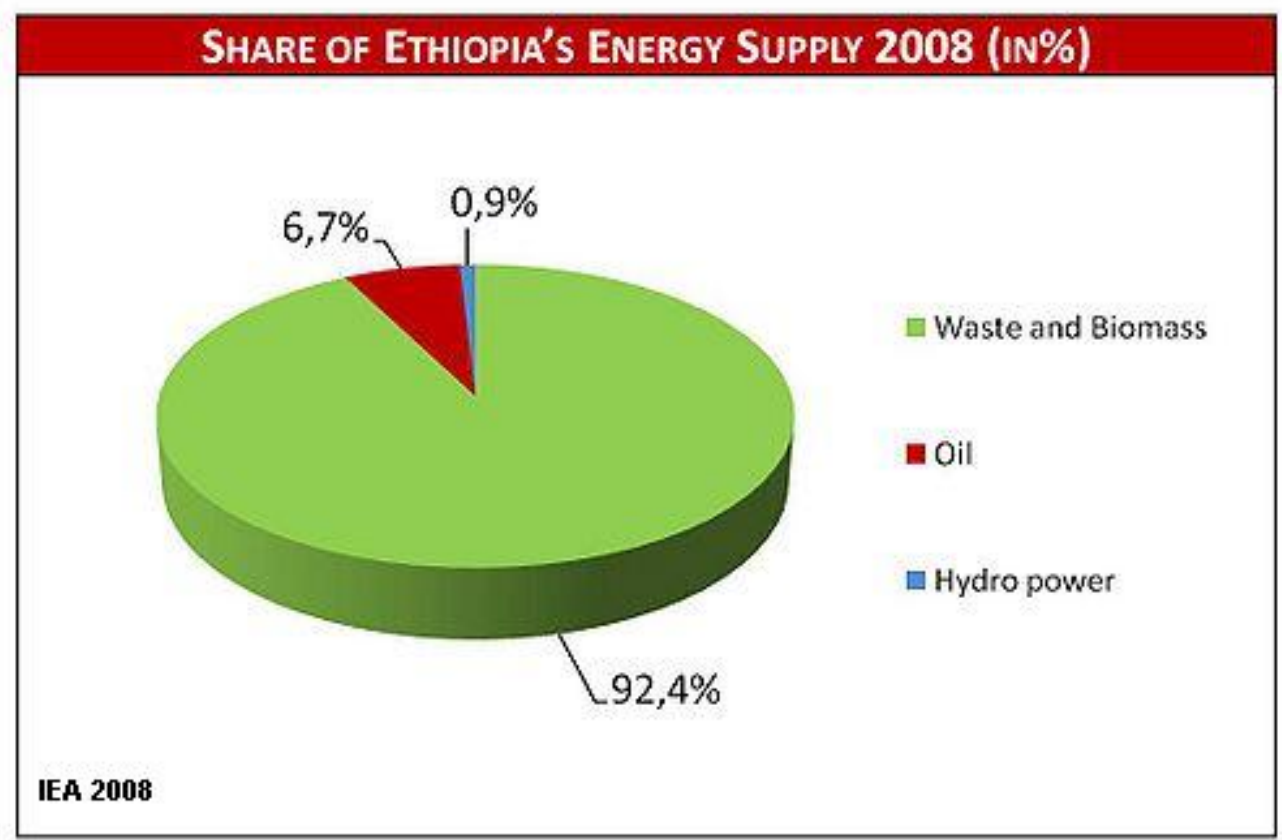

Are there any advantages with such a skewed energy mix? No, because even mainly rural Ethiopia delivers with lots of CO2: - see Figure 18.

FIGURE 18. Ethiopia: GDP and C02: $y=0,90 x, R^{2}=0,88$

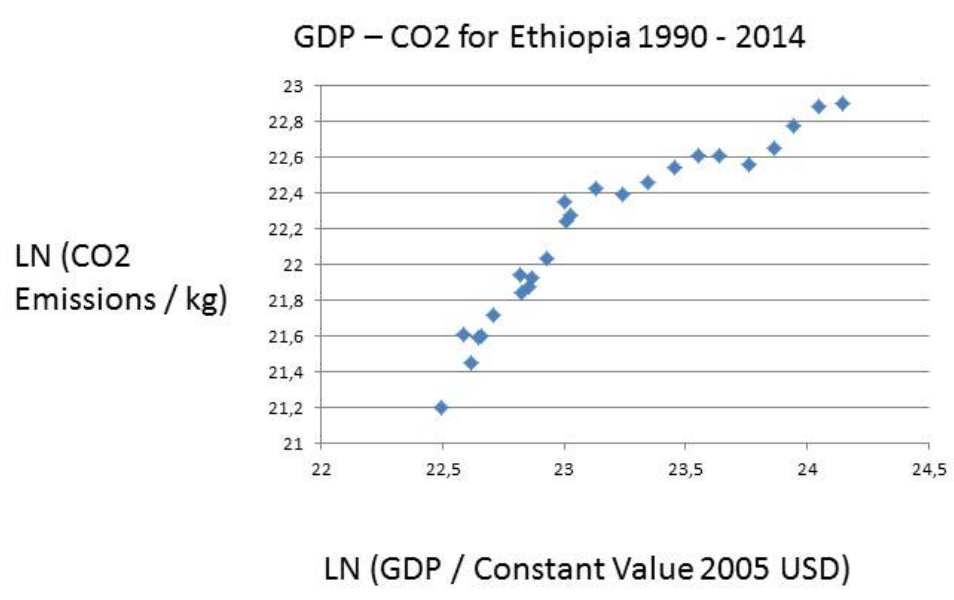

The zest with which Ethiopia is pursuing its control over water resources becomes fully understandable. What we see is the same smooth linear function plotting C02:s upon GDP, as is obvious in countries based upon fossil fuels - see below. For Ethiopia, to comply with COP21 goals is going to pose major challenges, especially if economic development is not going to be reduced. The country needs massive help, both financially and technologically. 
The Grand Ethiopian Renaissance Dam in Ethiopia and the Merowe Dam in Sudan bring electricity to Africa. Hydro power could be much more exploited in several African countries, but time is running out. Global warming reduces rivers and enhances draughts. Solar power is the future for all nations, whatever pattern of energy consumption they now have.

\section{CONCLUSION}

Poverty and especially water shortage on the African continent reflects the energy situation. Yet, as African nations increase energy, they must at the same time reduce CO2: s. The COP project is a great opportunity for African peoples, but the promise of support must really be forthcoming. New energy must be directed to secure water resources, construct sewage plants, halt overfishing and safeguard access to potable water. The use of wood coal in connection with deforestation is very bad. A sustinable future for Africa (Sachs, 2015) is offered by massive investments in solar power, and time presses (Stern, 2007, 2015).

\section{References}

\section{GDP sources:}

World Bank national accounts data - data.worldbank.org

OECD National Accounts data files

\section{GHG and energy sources:}

World Resources Institute CAIT Climate Data Explorer - cait.wri.org

EU Joint Research Centre Emission Database for Global Atmospheric

Research - http://edgar.jrc.ec.europa.eu/overview.php

UN Framework Convention on Climate Change -

http://unfccc.int/ghg_data/ghg_data_unfccc/time_series_annex_i/items/3814.php

International Energy Agency. Paris.

Energy Information Administration. Washington, DC.

BP Energy Outlook 2016.

EU Emissions Database for Global Research EDGAR,

http://edgar.jrc.ec.europa.eu/

World Bank Data Indicators, data.worldbank.org

British Petroleum Statistical Review of World Energy 2016

Environmental Performance Index, Yale University, https://epi.envirocenter.yale. IEA Statistics (C) OECD/IEA 2014 (http://www.iea.org/stats/inde

Environmental Performance Index, Yale University, https://epi.envirocenter.yale. IEA Statistics (C) OECD/IEA 2014 (http://www.iea.org/stats/inde

\section{Literature}

Sachs, J.D. (2015) The Age of Sustainable Development. New York: Columbia University Press.

Stern, N. (2007) The Economics of Climate Change. Oxford: Oxford University Press.

Stern, N. (2015) What are we waiting for? Cambridge: MA: MIT Press. 